\title{
Comparative Study on Erythrogram Parameters of Cell-Dyn Ruby and HumaCount 5L
}

\author{
Estudio Comparativo de los Parámetros del Eritrograma de Cell-Dyn Ruby y HumaCount 5L
}

\author{
Camila Carrasco $^{1}$; Danitza Carrasco ${ }^{1}$; Karina Godoy ${ }^{2,3}$; Mariano del Sol $^{4} \&$ Cristian Sandoval $^{1,5}$
}

CARRASCO, C.; CARRASCO, D.; GODOY, K.; DEL SOL, M. \& SANDOVAL, C. Comparative study on erythrogram parameters of Cell-Dyn Ruby and HumaCount 5L. Int. J. Morphol., 38(6):1618-1622, 2020.

SUMMARY: The use of hematological counts for the prevention, diagnosis and follow-up of hematological diseases has increased. Indeed, the correct operation of a clinical laboratory is essential to producing comparable results. However, there is a paucity of validation and reproducibility studies among the different existing methods for clinical analysis. Therefore, our aim was to assess the commutability of the results provided by analyzers with different measuring systems. Sixty venous blood samples were obtained from patients, without discriminating for age or sex. Then, an automated hematological analysis was performed using the Cell-Dyn Ruby and HumaCount 5L instruments. The variables measured were: RBC, Hb, HCT, MCV, MCH and MCHC. The data were compared by a one-way ANOVA and Pearson's correlation coefficient. Statistical significance was fixed at $p<0.05$. There were no statistically significant differences for $\mathrm{RBC}, \mathrm{HCT}, \mathrm{MCH}$ or MCHC. In addition, with the exception of MCHC, all the analytes showed a good correlation coefficient between the two instruments. There is a variety of automated systems for the clinical laboratory and it is essential for the clinician to know the different methodologies used in hematological analyzers as well as their sensitivity and specificity. Therefore, our results are useful for demonstrating the importance of practical knowledge of the analyzers mentioned.

KEY WORDS: Cytology; Epidemiology; Flow Cytometry; Hematology; Public Health.

\section{INTRODUCTION}

With the increased demand for hematological counts for the prevention, diagnosis and follow-up of hematological diseases, the need to create methods for faster and more effective analyses has been fundamental in recent decades, giving rise to the emergence of various hematological analyzers. Although manual methods have been ruled out due to the runtime required for the clinical analysis of each of the hematological parameters analyzed, these continue to be used to assess the discrepancies arising from automated methods.

Indeed, the correct operation of a clinical laboratory is indispensable if comparable and traceable results are to be produced regardless of the measuring principle used by the different analyzers available in order to reliably assist with a patient's hematological performance (Castillo de Sánchez \& Fonseca Yerena, 1995). However, due to various errors committed in the pre-analytical, analytical and postanalytical phases, this does not always occur (Akiyoshi, 1978; Lewis, 1988).

There is currently a myriad of methods for determining hematological parameters, thereby increasing the variability and number of automated analyzers available for in vitro diagnosis in the clinical laboratory.

Nowadays, blood cells are examined and differentiated by physical and/or cytochemical characteristics thanks to the emergence and development of new cell study technologies. For the normal operation of hematological analyzers, several measuring principles have been created, with flow cytometry and electrical impedance being the most frequently used.

\footnotetext{
${ }^{1}$ Carrera de Tecnología Médica, Facultad de Medicina, Universidad de La Frontera, Temuco, Chile.

${ }^{2}$ Núcleo Científico-Tecnológico en Biorecursos (BIOREN), Universidad de La Frontera, Temuco, Chile.

${ }^{3}$ Programa de Doctorado en Ciencias Morfológicas, Facultad de Medicina, Universidad de La Frontera, Temuco, Chile.

${ }^{4}$ Centro de Excelencia en Estudios Morfológicos y Quirúrgicos (CEMyQ), Facultad de Medicina, Universidad de La Frontera, Temuco, Chile.

${ }^{5}$ Departamento de Ciencias Preclínicas, Facultad de Medicina, Universidad de La Frontera, Temuco, Chile.

Research Funding: Funded by Dirección de Investigación, Proyecto DI20-0003, Universidad de La Frontera, Temuco, Chile.
} 
On the one hand, the Cell-Dyn Ruby model uses light scattering, where the suspended cells are aligned and pass through a small area with a perpendicular halogen light beam or laser, which causes the interruption and light scattering of the radiant energy at various angles. The number of light beam interactions corresponds to the number of cells that pass through the sensitive area of the instrument and the magnitude of their dispersion will be a function of different cell properties or characteristics, including volume, size, contour and refractive index, which is a function of the cell content, such as: presence of granulations, coloration, nuclear lobulation, and others (Juo, 2002; Villarrubia, 2002; Lewis et al., 2006; González de Buitrago, 2010; HernándezReyes, 2013).

By contrast, the hematological automated analyzer HumaCount 5L uses electrical impedance, where a total blood sample is diluted in an electrolyte solution and then passed in a line through an opening of determined diameter through which an electrical current circulates, induced by 2 electrodes placed on either side of the opening. As each cell passes through the opening, it causes a change in the electrical resistance that generates a voltage pulse, the height or amplitude of which must be proportional to the cell size or volume. Thus, the number of electrical pulses generated is related to the number of cells that pass through the opening. The advantages of this technology include its simplicity, low cost, the possibility of application in even the smallest instruments and its notable usefulness for the measurement of cell volumes. At present, this principle is applied as a reference method for blood cell counts and measuring the sizes of each cell population. It is used by most manufacturers of hematological counters due to its clear reproducibility, speed and reduction in statistical error (Villarrubia; Bentahar \& Izasa, 2006; Lewis et al.; González de Buitrago; Hernández-Reyes).

Given the paucity of validation and reproducibility studies among the different existing methods for clinical analysis of the erythrogram, the aim of this study was to evaluate the commutability of the results provided by analyzers with different measuring systems, in this case the automated analyzers HumaCount 5L and Cell-Dyn Ruby.

\section{MATERIAL AND METHOD}

Venous blood samples were collected in K3-EDTA vacuum tubes from 60 patients, without discriminating for age or sex, who attended the Complejo Asistencial Miraflores in Temuco, Chile. The erythrogram data were collected in the hematology section of the clinical laboratory at the Complejo Asistencial Miraflores and analyzed using Cell-Dyn Ruby and HumaCount $5 \mathrm{~L}$ according to the protocols for evaluation accuracy of the quantitative measurement methods (EP5-A2) suggested by the National Committee for Clinical Laboratory Standards and the International Council for Standardization in Hematology (National Committee for Clinical Laboratory Standards, 2004). The samples were kept at room temperature $\left(18-20^{\circ} \mathrm{C}\right)$ between $30 \mathrm{~min}$ and $4 \mathrm{~h}$ after collection until the evaluations were performed in the two analyzers, calibrated once a day according to the manufacturers' instructions.

The hematological variables analyzed were: red blood cells (RBC), hemoglobin (Hb), hematocrit (HCT), mean corpuscular volume (MCV), mean corpuscular hemoglobin $(\mathrm{MCH})$ and mean corpuscular hemoglobin concentration (MCHC).

The data collected from the hematological analyzers, Cell-Dyn Ruby and HumaCount 5L, were compared by means of a one-way ANOVA and Pearson's correlation coefficient. Statistical significance was fixed at $p<0.05$.

\section{RESULTS}

Table I provides a summary of the main characteristics of the methodologies used by the automated analyzers Cell-Dyn Ruby and HumaCount 5L.

To ascertain whether the hematological automated analyzers Cell-Dyn Ruby and HumaCount $5 \mathrm{~L}$ yield similar results for the measurements of the hemogram, each of the erythrogram parameters were compared using one-way

Table I. Main characteristics of the Cell-Dyn Ruby and HumaCount 5L instruments.

\begin{tabular}{lll}
\hline Analytes & Cell-Dyn Ruby & HumaCount 5L \\
\hline RBC & Flow cytometry & Electrical impedance \\
Hb & Spectrophotometry & Spectrophotometry \\
HCT & Calculated & Calculated \\
MCV & Optical laser light & Electrical impedance \\
HCM & Optical laser light and calculated & Calculated \\
CHCM & Optical laser light and calculated & Calculated \\
\hline
\end{tabular}

RBC: red blood cells; Hb: hemoglobin; HCT: hematocrit; MCV: mean corpuscular volume; $\mathrm{MCH}$ : mean corpuscular hemoglobin; MCHC: mean corpuscular hemoglobin concentration. 
ANOVA. The results are provided in Table II and indicate statistically significant differences for the RBC, HCT, MCH and MCHC analytes. The variability of the data, i.e., the random error for both instruments, is in Table III. Using Pearson's correlation coefficient as presented in Figure 1, the data collected from the Cell-Dyn Ruby and HumaCount $5 \mathrm{~L}$ were compared. The results for all the analytes studied are described in Table IV. With the exception of the MCHC, all the analytes showed a good correlation coefficient between the two instruments. The MCV presented had no statistically significant differences. The random error between the two instruments (1-R2) was for MCV (98\%), MCHC (90\%), MCH (19\%), HCT (7\%), Hb (4\%) and RBC (3\%). The systematic error (1-b) indicated differences ranging from 0 to $9.9 \%$ for the $\mathrm{Hb}, \mathrm{HCT}$ and MCV analytes; from 10 to $20 \%$ for RBC and $\mathrm{MCH}$, whereas it was $73 \%$ for the MCHC when they were analyzed by the two instruments.

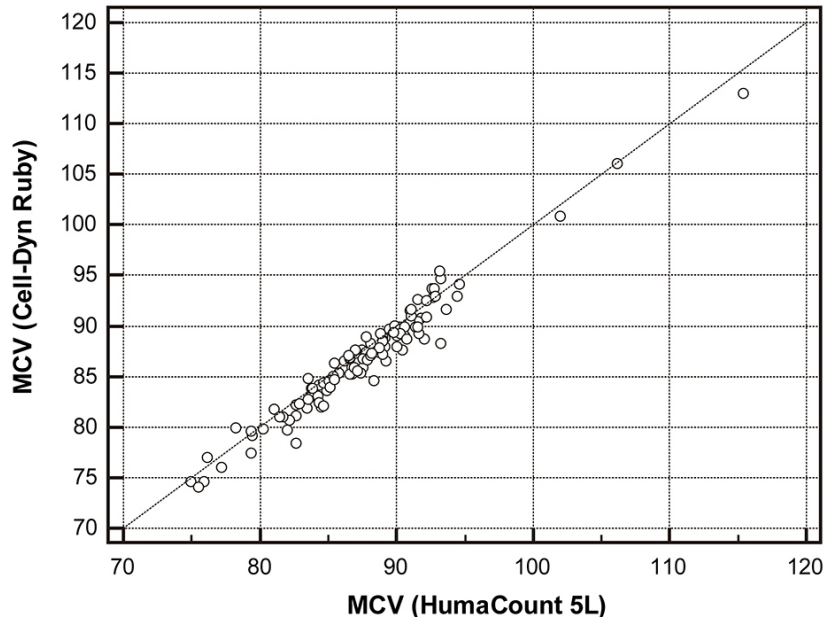

Fig. 1. Data on the mean corpuscular volume in the Cell-Dyn Ruby automated analyzer based on the data collected in the HumaCount $5 \mathrm{~L}$.

Table II. One-way ANOVA for the comparison of the erythrogram data obtained with the automated analyzers Cell-Dyn Ruby and HumaCount 5L and their respective reference ranges.

\begin{tabular}{lcccc}
\hline \multicolumn{1}{c}{ Analytes } & Instruments & ANOVA $\boldsymbol{p}$ & \multicolumn{2}{c}{ Reference intervals } \\
\hline $\mathrm{RBC}(/ \mathrm{mm} 3)^{*}$ & Cell-Dyn Ruby & 0.005 & 4.0 & 6.2 \\
& HumaCount 5L & & 4.0 & 5,5 \\
$\mathrm{Hb}(\mathrm{g} / \mathrm{dL})$ & Cell-Dyn Ruby & 0.62 & 11.0 & 17.0 \\
& HumaCount 5L & & 12.0 & 17.4 \\
$\mathrm{HCT}(\%)^{*}$ & Cell-Dyn Ruby & 0.022 & 35.0 & 55.0 \\
& HumaCount 5L & & 36.0 & 52.0 \\
$\mathrm{MCV}(\mathrm{fL})$ & Cell-Dyn Ruby & 0.405 & 80.0 & 100.0 \\
& HumaCount 5L & & 76.0 & 96.0 \\
$\mathrm{MCH}(\mathrm{pg})^{*}$ & Cell-Dyn Ruby & $<0.001$ & 26.0 & 34.0 \\
& HumaCount 5L & & 27.0 & 32.0 \\
$\mathrm{MCHC}(\mathrm{g} / \mathrm{dl})^{*}$ & Cell-Dyn Ruby & $<0.001$ & 31.0 & 35.5 \\
& HumaCount 5L & & 30.0 & 35.0 \\
\hline
\end{tabular}

*: Statistically significant differences (ANOVA, $\mathrm{p}<0.05$ ); $\mathrm{p}$ : probability of error for the null hypothesis RBC: red blood cells; Hb: hemoglobin; HCT: hematocrit; MCV: mean corpuscular volume; MCH: mean corpuscular hemoglobin; and MCHC: mean corpuscular hemoglobin concentration.

Table III. Average intra-day and inter-day variability for the erythrogram data obtained from the automated analyzers Cell-Dyn Ruby and HumaCount $5 \mathrm{~L}$

\begin{tabular}{lccrr}
\hline & \multicolumn{2}{c}{ Cell-Dyn Ruby } & \multicolumn{2}{c}{ HumaCount 5L } \\
Analytes & Intra - day & Inter - day & Intra - day & Inter - day \\
\hline RBC (/mm3)* & $4.32 \pm 0.55(12.9 \%)$ & $4.39 \pm 1.02(14.6 \%)$ & $4.54 \pm 0.61(13.5 \%)$ & $4.60 \pm 1.08(15.2 \%)$ \\
Hb (g/dL) & $13.45 \pm 1.56(11.6 \%)$ & $13.32 \pm 1.88(14.1 \%)$ & $13.52 \pm 1.63(12.1 \%)$ & $13.42 \pm 1.94(14.5 \%)$ \\
HCT (\%)* & $37.64 \pm 4.21(11.2 \%)$ & $37.41 \pm 5.68(13.6 \%)$ & $38.95 \pm 4.55(11.7 \%)$ & $38.76 \pm 6.05(14.1 \%)$ \\
MCV (fL) & $87.55 \pm 5.09(5.8 \%)$ & $86.18 \pm 12.22(11.1 \%)$ & $86.18 \pm 5.51(6.4 \%)$ & $85.11 \pm 11.92(10.9 \%)$ \\
MCH (pg)* & $31.30 \pm 2.48(7.9 \%)$ & $30.58 \pm 4.10(11.4 \%)$ & $29.91 \pm 2.10(7.0 \%)$ & $29.38 \pm 3.92(11.2 \%)$ \\
MCHC (g/dl)* & $35.73 \pm 1.13(3.2 \%)$ & $34.84 \pm 4.52(9.7 \%)$ & $34.70 \pm 1.01(2.9 \%)$ & $33.88 \pm 4.39(9.6 \%)$ \\
\hline
\end{tabular}

RBC: red blood cells; Hb: hemoglobin; HCT: hematocrit; MCV: mean corpuscular volume; MCH: mean corpuscular hemoglobin; and MCHC: mean corpuscular hemoglobin concentration. Mean \pm standard deviation (coefficient of variation). A total of 60 samples were processed with the two automated instruments. 
CARRASCO, C.; CARRASCO, D.; GODOY, K.; DEL SOL, M. \& SANDOVAL, C. Comparative study on erythrogram parameters of Cell-Dyn Ruby and HumaCount 5L. Int. J. Morphol., 38(6):1618-1622, 2020.

Table IV. Regression analysis for the erythrogram data obtained from the automated analyzers Cell-Dyn Ruby and HumaCount 5L.

\begin{tabular}{lcccccc}
\hline & \multicolumn{2}{c}{ Regression } & \multicolumn{2}{c}{ Correlation } & \multicolumn{2}{c}{ Errors } \\
\hline \multicolumn{1}{c}{ Analytes } & $\mathrm{a}$ & $\mathrm{b}$ & $\mathrm{R}$ & $\mathrm{p}$ & $1-\mathrm{R}^{2}$ & $1-\mathrm{b}$ \\
\hline $\mathrm{RBC}\left(/ \mathrm{mm}^{3}\right) *$ & 0.337 & 0.880 & 0.984 & $<0.0001$ & 0.032 & 0.120 \\
$\mathrm{Hb}(\mathrm{g} / \mathrm{dL})$ & -0.265 & 1.027 & 0.977 & $<0.0001$ & 0.045 & -0.023 \\
$\mathrm{HCT}(\%)^{*}$ & -0.798 & 1.056 & 0.961 & $<0.0001$ & 0.076 & -0.056 \\
$\mathrm{MCV}(\mathrm{fL})$ & 0.555 & 0.984 & 0.125 & 0.1907 & 0.984 & 0.016 \\
$\mathrm{MCH}(\mathrm{pg})^{*}$ & 4.079 & 0.831 & 0.896 & $<0.0001$ & 0.197 & 0.169 \\
$\mathrm{MCHC}(\mathrm{g} / \mathrm{dl})^{*}$ & 24.934 & 0.269 & 0.305 & 0.0011 & 0.907 & 0.731 \\
\hline
\end{tabular}

a: linear coefficient; b: angular coefficient; R: Pearson's correlation coefficient; 1-R2: random error; 1-b: systematic error. *: Statistically significant differences (ANOVA, p < 0.05). RBC: red blood cells; Hb: hemoglobin; HCT: hematocrit; MCV: mean corpuscular volume; MCH: mean corpuscular hemoglobin; and MCHC: mean corpuscular hemoglobin concentration and RDW: red cell distribution width.

\section{DISCUSSION}

Blood cell count and hematocrit are parameters of the hemogram that provide information for the classification and diagnosis of anemias as well as for the follow-up of their evolution and monitoring of the treatment. As previously mentioned, analytical systems must be standardized and subjected to strict quality control to provide traceable hematological results in terms of accuracy and reproducibility (Palomo et al., 2009).

Of the parameters analyzed in both instruments, those that had statistically significant differences were: RBC, HCT, $\mathrm{MCH}$ and MCHC (Table II). These significant differences in the red blood cell count may be because Cell-Dyn Ruby uses flow cytometry, a technology based on suspended cells or other particles being lined up and passing in front of a light beam. The data produced can be grouped into two fundamental types: data generated by light scattering and data related to the emission of light by the fluorochromes present in the cell or particle to be excited by the light beam, which ensures that the same cell will not be counted more than once. By contrast, HumaCount 5L uses electrical impedance technology, which could cause the blood cells to be counted more than once as a result of their recirculation inside the count opening. Although these cells tend to produce smaller impulses than the cells that pass through the opening the first time, they contribute to the erythrocyte count (Fink, 2005). Thus, the blood cell count is greater with the electrical impedance method than with flow cytometry, the principle of which is more accurate (Barrera Ramírez et al., 2004).

The reference method to determine hemoglobin is the photometric detection of cyanmethemoglobin (International Committee for Standardization in Haematology, 1967). However, it has certain disadvantages, including requiring the extraction of $3 \mathrm{~mL}$ of blood for each determination, at least 30 minutes for the results and the use of cyanide, a reagent toxic to health and the environment. Therefore, alternative reagents have been proposed, such as sodium azide (Vanzetti, 1966) and sodium lauryl sulfate, with the latter being used by Cell-Dyn Ruby and HumaCount 5L to convert hemoglobin into sulfate hemoglobin (Bain et al., 2012).

With respect to HCT, the differences can be explained by the form in which such indices are obtained. In the CellDyn Ruby analyzer, HCT is obtained via a mathematical calculation that relates RBC and MCV determined by the automated analyzer, applying the following formula:

By contrast, in the HumaCount $5 \mathrm{~L}, \mathrm{HCT}$ is determined directly by the sum of the pulses of all the red blood cells verified in the volume of sample analyzed.

Today, the effects of abnormally deformed red blood cells on the MCHC estimation (Kickler, 1999) in impedance analyzers are known. Indeed, shear stress in red blood cells causes cellular deformation, which is inversely proportional to the viscosity, which in turn depends on the MCHC (Henneberg et al., 2011); therefore, the higher the MCHC value, the greater the cellular viscosity, and consequently the lower the deformation of the cell (Van Hove et al., 2000; Rappaz et al., 2008).

Based on the results obtained, it can be suggested that the $\mathrm{MCHC}$ in the HumaCount $5 \mathrm{~L}$ analyzer is more sensitive than the parameter of evaluating erythrocyte color than Cell-Dyn Ruby, mainly due to the use of the hydrodynamic approach in the HumaCount 5L.

There is currently a variety of automated systems for the clinical laboratory. For this reason, it is essential for the clinician to be aware of the different methodologies used in 
the hematological analyzers, the levels of accuracy and precision, as well as the sensitivity and specificity of each erythrogram parameter. Therefore, the results obtained here are useful for demonstrating the importance of practical knowledge of the analyzers mentioned.

CARRASCO, C.; CARRASCO, D.; GODOY, K.; DEL SOL, M. \& SANDOVAL, C. Estudio comparativo de los parámetros del eritrograma de Cell-Dyn Ruby y HumaCount 5L. Int. J. Morphol., 38(6):1618-1622, 2020.

RESUMEN: El uso de recuentos de células sanguíneas para la prevención, diagnóstico y monitoreo de enfermedades hematológicas ha ido en aumento. Por ello, el funcionamiento correcto de un laboratorio clínico es indispensable para producir resultados comparables. Sin embargo, existen pocos estudios de validación y reproducibilidad de los diferentes métodos de análisis clínico existentes. Por lo tanto, nuestro objetivo fue evaluar la intercambiabilidad de los resultados entregados por los analizadores que utilizan diferentes sistemas de medición. Se obtuvieron sesenta muestras de sangre venosa de pacientes, sin discriminar por edad o sexo. Los eritrogramas fueron obtenidos utilizando los analizadores automatizados Cell-Dyn Ruby y HumaCount 5L. Las variables medidas fueron: RBC, Hb, HCT, MCV, MCH y MCHC. Los datos fueron comparados por ANOVA a una vía y la correlación de Pearson. La significación estadística se estableció en el nivel estándar $\mathrm{p}<0,05$. No hubo diferencias estadísticamente significativas para RBC, HCT, MCH y MCHC. Con la excepción de la $\mathrm{MCHC}$, todos los analitos presentaron un buen coeficiente de correlación entre los dos analizadores comparados. Existen varios sistemas de automatización para su uso en laboratorios clínicos. Por lo tanto, es primordial para el clínico estar familiarizado con las diferentes metodologías utilizadas en los analizadores de sangre, así como su sensibilidad y especificidad. Nuestros resultados son útiles para mostrar la importancia del conocimiento práctico de los diferentes sistemas de medidas comparados.

PALABRAS CLAVE: Citología; Epidemiología; Citometría de Flujo; Hematología; Salud Pública.

\section{REFERENCES}

Akiyoshi, H. T. Control de calidad interlaboratorial en la Argentina: primer programa nacional de encuestas de química clínica realizado por el Comité de Estandarización y Control de Calidad, CECC. Med. Atl., 18:289-94, 1978.

Bain, B. J.; Bates, I.; Laffan, M. A. \& Lewis, S. M. Dacie and Lewis: Practical Haematology. 11 ${ }^{\text {th }}$ ed. Amsterdam, Elsevier, 2012.

Barrera Ramírez, L. M.; Drago Serrano, M. E.; Pérez Ramos, J.; Zamora, A. C.; Gómez Arroyo, F.; Sainz Espuñes, T. R. \& Mendoza Pérez, F. Citometría de flujo: vínculo entre la investigación básica y la aplicación clínica. Rev. Inst. Nal. Enf. Resp. Méx., 17(1):42-55, 2004.

Bentahar, A. \& Izasa, S. A. Nuevas aplicaciones clínicas en los analizadores hematológicos de la serie LH. Haematologica, 91(Suppl. 1):146-9, 2006.
Castillo de Sánchez, M. L. \& Fonseca Yerena, M. E. Mejoría Continua de la Calidad: Guía para los Laboratorios Clínicos de América Latina. Ciudad de México, Médica Panamericana, 1995.

Fink, N. E. Automatización en hematología. Hematología, 9(1):4-16, 2005.

González de Buitrago, J. M. Tecnología y métodos de laboratorio clínico. Barcelona, Elsevier Masson, 2010.

Henneberg, R.; do Nascimento, A. J.; Cicchetti, D. V.; Ferreira, A. E.; Andrade, C. \& Franco, M. Estudio comparativo de parámetros del eritrograma del Coulter STKS y del Sysmex XE-2100D. Acta Bioquim. Clin. Latinoam., 45(4):757-62, 2011.

Hernández-Reyes, L. H. Avances y aplicación clínica de la citometría hemática automatizada. Rev. Cuba. Hematol. Inmunol. Hemoter. 29(1):24-39, 2013.

International Committee for Standardization in Haematology. Recommendations for haemoglobinometry in human blood. $\mathrm{Br}$. $\mathrm{J}$. Haematol., 13:71-5, 1967.

Juo, J. M. Análisis automatizado de las poblaciones eritrocitarias: su aplicación en el diagnóstico de las anemias. Haematologica, 87(Suppl. 1):120-34, 2002

Kickler, T. S. Clinical analyzers. Advances in automated cell counting. Anal. Chem., 71(12):363R-365R, 1999.

Lewis, S. M. The WHO International External Quality Assessment Scheme for haematology. Bull. World Health Organ., 66(3):283-90, 1988.

Lewis, S. M.; Bain, J. \& Bates, I. Dacie and Lewis: Practical Haematology. $10^{\text {th }}$ ed. Philadelphia, Churchill Livingston Elsevier, 2006.

National Committee for Clinical Laboratory Standards. Evaluation of Precision Performance of Quantitative Measurement Methods. 2nd ed. Pennsylvania, NCCLS, 2004.

Palomo, I.; Pereira, J. \& Palma, J. Hematología: Fisiología y Diagnóstico. Talca, Editorial Universidad de Talca, 2009.

Rappaz, B.; Barbul, A.; Emery, Y.; Korenstein, R.; Depeursinge, C.; Magistretti, P. J. \& Marquet, P. Comparative study of human erythrocytes by digital holographic microscopy, confocal microscopy, and impedance volume analyzer. Cytometry A, 73(10):895-903, 2008.

Van Hove, L.; Schisano, T. \& Brace, L. Anemia diagnosis, classification, and monitoring using Cell-Dyn technology reviewed for the new millennium. Lab. Hematol., 6:93-108, 2000.

Vanzetti, G. An azide-methemoglobin method for hemoglobin determination in blood. J. Lab. Clin. Med., 67(1):116-26, 1966.

Villarrubia, J. Avances en el diferencial leucocitario automatizado. Criterios para la revisión del hemograma y sistemas expertos de validación automática. Haematologica, 87(Suppl. 1):138-42, 2002.

Corresponding author:

Dr. Cristian Sandoval

Departamento de Ciencias Preclínicas

Facultad de Medicina

Universidad de La Frontera

Avenida Francisco Salazar 01145

Casilla 54-D

Temuco- CHILE

Email: cristian.sandoval@ufrontera.cl

Received: 20-05-2020

Accepted: 29-06-2020 